\title{
Android App for Information of Food Additives contained in Packaged Foods
}

\author{
Umi Saádah ${ }^{1}$, Tita Karlita ${ }^{1}$, and Muchammad Arfian $^{1}$
}

\begin{abstract}
Today, the usage of food additives can be found in nearly every food, especially in packaged foods. Meanwhile, the majority of people are unaware of the impact of the use of food additives in the human body when consumed freely. One of the easiest ways to determine the ingredients of a packaged food, is to read the label of product composition. If it is doubtful, then the product was not consumed. However, public knowledge about food ingredients listed in the product composition is generally relatively low. So, even if they could determine the ingredients of the packaged food products, but still do not know the impact of their use. In this research, built an Android app of Food Additives Glossary that presents information about each type of food additives. This app has a barcode scanner and decoder using ZXing library to facilitate the acquisition of data from the food additives listed in packaged foods. User reads the barcode of packaged food products using the barcode scanner. This applications will display of food additives contained therein. Furthermore, the user can select one of the food additives and the application will display some information, such as: INS code, category (safety, unhealthy, dangerous), ADI (Acceptable Daily Intake) limits, side effects and further description of the food additives.
\end{abstract}

Keywords— Food Additives Glossary, Packaged Food, Barcode, Scanner, ADI.

\section{INTRODUCTION}

$\mathrm{F}$ ood additives are substances that are not normally used as food and usually are not typical food raw materials. They have or do not have the nutritional value, which is intentionally added to food in order to get benefits or change the desired nature in the manufacture, processing, preparation, treatment, packing, packaging, storage or transportation of food. The goal is to produce or is expected to produce a component or affect the distinctive nature of the food [6].

Since the middle of the 20th century, the role of food additives, particularly preservatives, are becoming increasingly important in line with advances in production technology of synthetic food additives. The number of food additives in the form of a more pure and commercially available at relatively low prices, encouraging the increased use of food additives. It also means an increase in the consumption of such materials for each individual.

The use of food additives can be found in nearly every food, especially food packaging. The dependence to the food packaged is tend to increase. Meanwhile, various food additives have a limit of consumption and the harmful effects that can cause diseases such as tumors, cancer and genetic disorders.

The usage of food additives preferably at a dose below the pre-determined threshold. There are two kinds of food additives that is GRAS (Generally Recognized as Safe) which is a kind of safe and no toxic effect, and ADI (Acceptable Daily Intake) which is always determined daily usage limit, in order to maintain or protect the health of consumers [2].

The majority of people do not know about the concept of ADI, which limits the total consumption of certain food additives, because it is not considered as a significant threat. Though its presence in food can cause dangerous diseases, especially those containing synthetic

${ }^{1}$ Umi Saádah, Tita Karlita, and Muchammad Arfian are with Departement of Electronic Engineering, Politeknik Elektronika Negeri Surabaya, Surabaya, 60111, Indonesia. E-mail: umi@eepis-its.edu; 2tita@eepis-its.edu; 3muchammad.arfian@gmail.com. food additives, which sometimes have carcinogenic. The properties can stimulate cancer if consumed exceeds the limit.

The importance of recognizing the food consumed, make the community began to realize and try to be a good consumer. Today, people not only interested in whether the taste of food, or whether the kids will enjoy the food that is served, but more than that, people have been interested in matters of food consumed whether it was good for him and what ingredients contained therein [3].

The lacks of access to information about food additives, making people have difficulty finding relevant information. A number of related researches have produced many books that explain about the food additives. However, most of the explanation is too complicated for people who do not have chemical or nutritional background.

Wisnu [3] discusses in detail the various food additives used legally in Indonesia, from the functional, medical analysis, how to detect a food additive with the chemical method, the maximum value of the content, and so on, based on the Regulation of the Minister of Health, 1998.

The origin of food additives could be derived from natural sources or biosynthesized from chemicals. Generally, synthetic materials have some advantages, i.e. more concentrated, more stable and less expensive. But instead, this process is often not perfect, so it contained substances that are harmful to people health [3].

Shane [4] discusses alternative packaged food using organic products as a way to minimize the consumption of food additives contained in packaged products. More than 500 food additives permitted its use in non-organic foods. Many of these foods do not undergo testing and production. While consumption continues without being questioned about its safety.

More use of food additives is also associated with several diseases such as allergies, rashes, headaches, asthma, growth retardation and hyperactivity in children. Danish researchers have calculated that one to two percent of school-age children have an intolerance to food additives, including preservatives, colorings and flavor enhancer [4]. 
Barbara [9] discusses food additives, contaminants, especially nickel and chrome, as well as the side effects caused by the consumption of these food additives. In the industrialized countries, over the last 50 years have shown a significant increase in the amount of preservatives and food additives are used in food prior to entry into the market.

The use of food additives has risen considerably in the last 30 years, with a total of more than 200,000 tons per year, with each individual consumes an average of 3.6 $4.5 \mathrm{~kg}$ of food additives. The impact of the increase in the rising cases of intolerance to food additives as well as the emergence of a variety of physical and mental illness, including hyperactivity and hypersensitivity in children.

The recommendation given is, when buying food, so need to be vigilant and always check the packaging label. If there is any doubt, then leave. Because this road is the only way that is safe to avoid the harmful effects of food additives [9].

SmartphoneDev developed an Android application which is found on Google Play. This application provides descriptive information about certain food additives by number. User performs a search on the search bar or browse the table of $400+$ well-known food additive. This application can also provide a warning to vegetarians, if found the additional food is derived from the flesh of animals[8].

This research is to build an application that can be used as an access to the appropriate information to the general public. With this application, people can understand the function and effect of each food additives if consumed. In use, users read existing barcode labels on food products using barcode scanner. The application will display information of food additives in the product. Next, the application will display the detailed information of the selected food additives.

\section{METHOD}

In this section, described the solution or the means used to deal with problems that have been described previously.

\section{A. System Design}

This app is designed based on client-server model. In the server, the admin can process and manipulate data that is used. While the client user can access the data via the android device. Overall system design of the application is in accordance with Figure 1.

Based on Figure 1, the program flow starts from the server that holds the data of food additives, packaged products and glossary. These data can then be accessed by a mobile device Android in JSON format. Furthermore, the data will be parsed and inserted into SQLite. In the use of the application, the data will be used for scanning products, read the information of certain additives, search, etc.

Monitoring data on the server is done by the Admin. Admin has the right to access, add, edit and delete data and also change the database version. The process of change the database version will affect to the client application, because when the version of the database changed, the application can also update the contents of the database.

\section{B. Application Design}

This section describes the design of applications, including the menus and various features in it.

1) Dashboard

Figure 2 is a view of the main page that will appear when the application's main opened. The page designed with a minimalist model of a two-column grid that contains the icon of the shortcut to the main features of the application. There are five main menus and two additional menus.

Additional menu will appear when the user press menu button in the device. In this additional menu, there are update and about menu. Update menu is the way that the user always gets the data and the latest information from the application. About menu, describes the information about the application.

2) List \& Search

This application has three search features: search of food additives, search of products and search of glossary. On each page there is a search box that can be used to enter data/information sought.

The search feature of food additives will help users find certain food additives, as shown in Figure 3 (a). On this page, the name of food additives are shown both locally and internationally name, together with INS code respectively. The searching can be done using search by local name (Indonesia), by international name (English) or by the code.

Figure 3(b) shows the search feature of product based on the product name. This page displayed the names of a number of products that are available on application. Product listed is a product that is known commonly encountered by the public. In this feature, the search facility is also provided to allow a user to find the specific product.

While Figure3(c), shows the search feature for glossary. On this page, displayed various terms about food additives are rarely known. The covered terms are to clarify the role of food additives, the effects of disease/syndrome and essential terms of food. This feature also comes with a search facility to allow users to find the desired term.

3) Profiles

This application has three profile features that can display the food additive profile, product profile and glossary profile.

Based on Figure 4 (a), food additives profile displays information related to certain food additives. In this case, there are three aspects that can be known through this application, i.e. general information, functions of food additives to food, and the halal status of the material. General information contains a variety of information, namely code, category, ADI limits, side effects as well as its description.

In this case, category represent condition or hypothesis of certain food additives analysis, i.e. safe, suspect, unhealthy, dangerous an unknown. As additional information, the category also be represented by the background color. The background color will change according to categories: safe (green), suspect (yellow), unhealthy (pink), dangerous (dark red).

Figure 4(b) displays the profile of food products: a little information about the product and a list of food additives contained in the product. This page also 
displays the product logo that aims to clarify and prevent ambiguity with other products. However, these additional features require an internet connection.

Figure 4(c) displays the glossary profile, which gives a detailed explanation of the term selected. The goal is to facilitate the user in understanding the primary information conveyed through this application

\section{RESULT AND DISCUSSION}

This section describes on how the application works, how the tests performed and the results obtained

\section{A. Testing}

Testing is done by running this app on several different devices to ensure the application runs properly. The specifications of the device that is used is as follows:

a. Sony Experia J

$\begin{array}{lll}\text { Screen } & \text { 4” } \\ \text { Android version } & \text { : Ice Cream Sa } \\ \text { CPU } & : 1 \mathrm{GHz} \text { Cortex - A5 } \\ \text { RAM } & : 512 \mathrm{MB} \\ \text { Camera } & : 5 \mathrm{MP} \text {, auto focus } \\ \text { SmartFren Max I } & \\ \text { Screen } & : & 4 \\ \text { Android version } & : \text { Jelly bean } \\ \text { CPU } & : & 1 \mathrm{GHz} \text { Cortex - A5 } \\ \text { RAM } & : 512 \mathrm{MB} \\ \text { Camera } & : 5 \mathrm{MP} \text {, auto focus }\end{array}$

1) Barcode Scanner Testing

The use of barcode scanners on the application can be done using the Zxing library integrated with applications such as Food Additive Glossary shown in Figure5. As the results of the integration, the application can access the Food Additive Glossary barcode scanner and get the results of the scan. If the device has not been used Barcode Scanner app, it will display a prompt to download it.

Barcode scanners is required to decode the barcode image that is on every packaged food. Table 1 lists the results of experiments conducted on some products.

In the Table 1, the column displays category of the security level of consumption, are divided into five types, namely:

a. Safe, which is a food additive with the lowest side effects or no side effects.

b. Suspect, ie food additives with medium and lower side effects that can affect health in a while.

c. Unhealthy, namely food additives that have high levels side effects and can affect health in the long run.

d. Dangerous, the food additives that have a high rate of side effects and can affect the health of a fatal disease.

e. Unknown, which is a food additive that has not identified the level of safety.

In the halal status column, displays information about a halal/haram status of food additives. Halal/haram value is obtained from the basic ingredients and how to make it. In this application there are five status halal/haram, namely:

a. Halal, is a status on food additives that are known materials and the manufacturing process is halal.

b. Halal conditional, is a status on food additives which would be halal if made of materials known with halal status, however, could be syubhat/doubtful if the material status is doubtful.

c. Doubtful, is a status on food additives made from materials or the manufacturing process assessed doubtful.

d. Haram, is a status on food additives are known materials and/or manufacturing process is haram.

e. Not known, is a status of food additives made of materials and/or processes are not known halal/haram.

In the process of this trial there are some difficulties in the use of barcode scanners. This is because on every android device has only one lens and sensor (red lines). This is in contrast with the barcode scanner is a separate hardware device, which is commonly found in the store cashier.

In addition, the difficulty of the scanner also occur for reasons as follows:

a. The surface of packaged foods that are not smooth and flat, such as curved or holes. This resulted in a barcode image is not straight and cannot be decoded.

b. Plastic food packaging that resulted in the reflection of light when being captured. This reflection also resulted barcode could not be decoded.

c. Barcode on packaging that is too small, so the user must perform zooming several times. This resulted in the barcode image looks blurry so it is difficult to be decoded. Because the barcode is actually the specificity principle between black and white as well as the width of each of the line [5].

\section{B. Update Process}

Update feature is the way that the user always gets the data and the latest information from the application. This feature can be done either automatically or manually which can be set in the application settings. Update feature is divided into three phases, namely: database in server checking (see Figure 6(a)), confirmation dialog (see Figure 6(b)) and download process (see Figure 6(c)),

In the automatic update settings, checking database in server (the first phase) will be done in a background process. If the new data is found, then the process will continue in the next phase.

\section{CONCLUSION}

From the results of the testing that has been done, it can be concluded that the barcode feature on this application can help users to identify the content of the food additives contained in the product packaging are tested. Furthermore, this application can also show the impact and risk of consuming such foods by featuring additional food categories and its halal status.

\section{REFERENCES}

[1]. Additives, Joint Expert Committee on Food. IPCS INCHEM. http://www.inchem.org/pages/jecfa.html (accessed March 14, 2013)

[2]. Administration, US Food and Drug. Everything Added to Food in the United States. CRC Press, Inc, 1993.

[3]. Cahyadi, Wisnu. Analisis dan Aspek Kesehatan Bahan Tambahan Pangan (edisi 2). Jakarta: Bumi Aksara, 2006.

[4]. Heaton, Shane. "Focus on Organic Food Quality : Food Additives.” (Australian Organic Journal) n.d. 
[5]. Malik, Jaja Jamaludin, Rachmadi Wijaya, and Ridho Taufiq S. Implementasi Teknologi Barcode dalam Dunia Bisnis. Yogyakarta: Andi Offset, 2010.

[6]. Menteri Kesehatan, Republik Indonesia. "Peraturan Menteri Kesehatan Republik Indonesia.” Bahan Tambahan Pangan, 20 September 1998.

[7]. - _. "Peraturan Menteri Kesehatan Republik Indonesia.” Bahan Tambahan Pangan, 27 July 2012.
[8]. SmartphoneDev. Food Additive Assistant. Google Play, 2011.

[9]. Wroblewska, Barbara. "Influence of Food Additives and Contaminants (Nickel and Chromium) on Hypersensitivity and Other Adverse Health Reactions - A Review.” (Institute of Animal Reproduction and Food Research of the Polish Academy of Sciences) 59, no. 4 (2009).

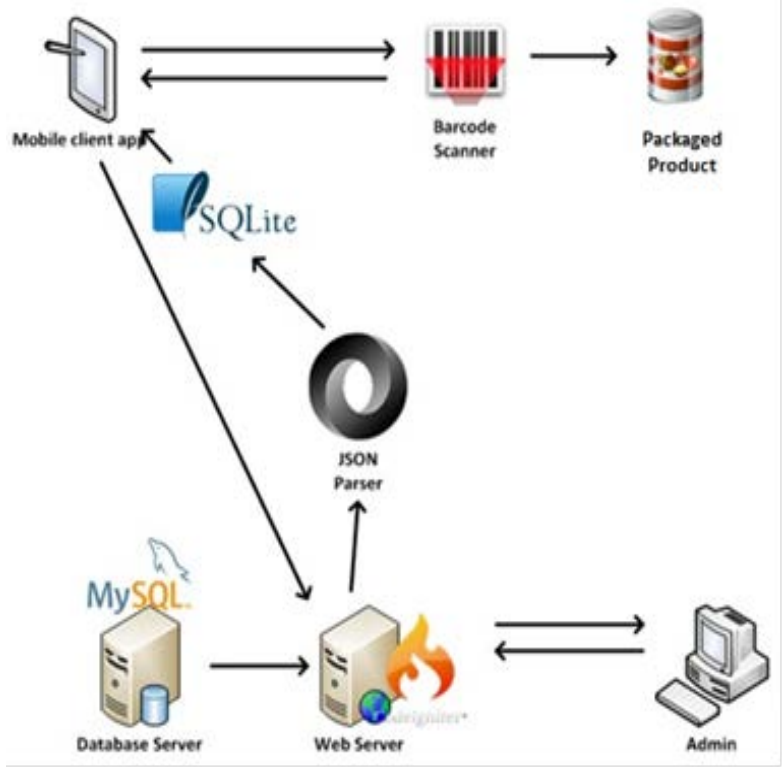

Figure 1. System Design

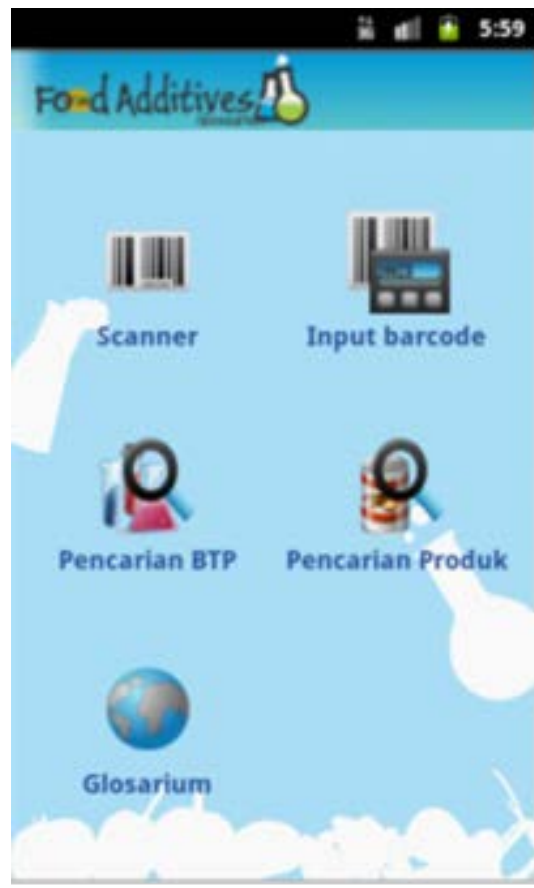

Figure 2. Dashboard Design

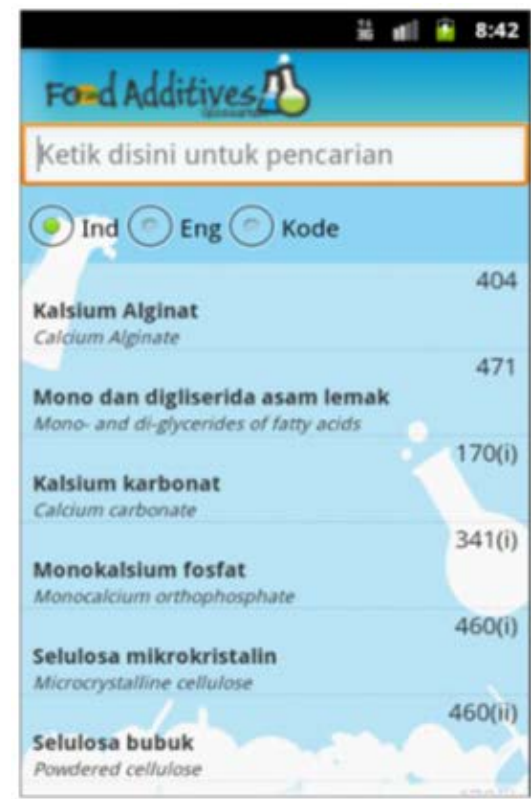

(a)

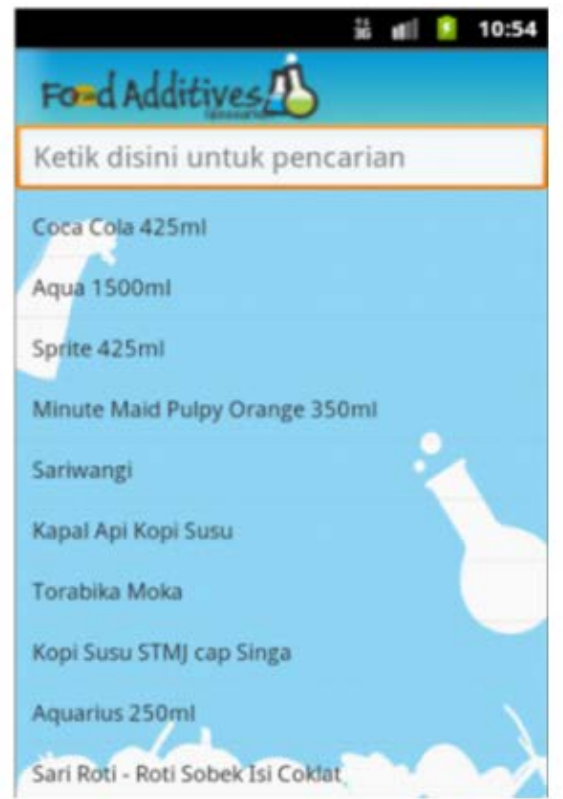

(b)

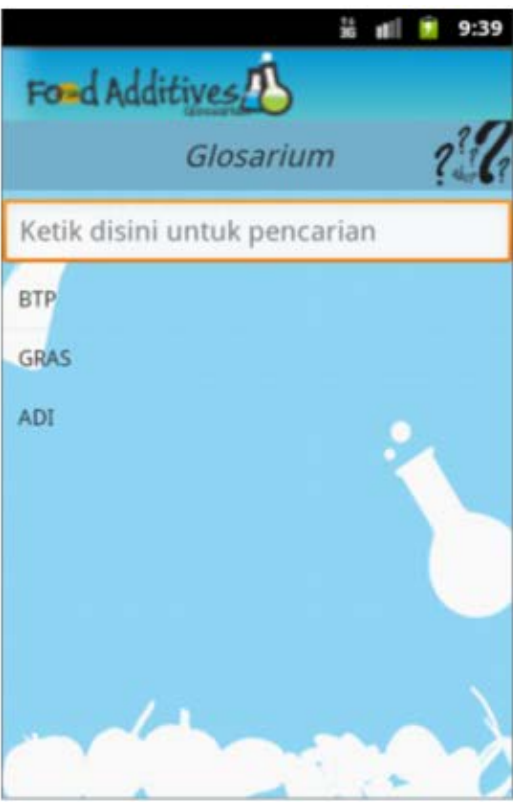

(c)

Figure 3. List and Search design. 


\section{in will $*$ 9:23}

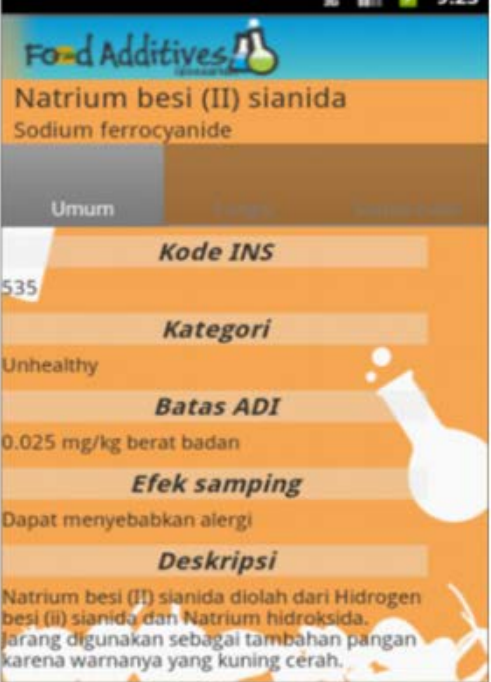

(a)

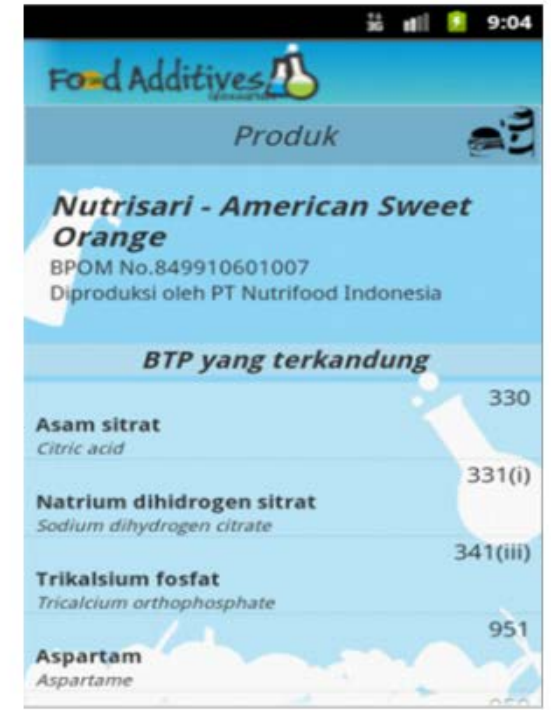

(b)

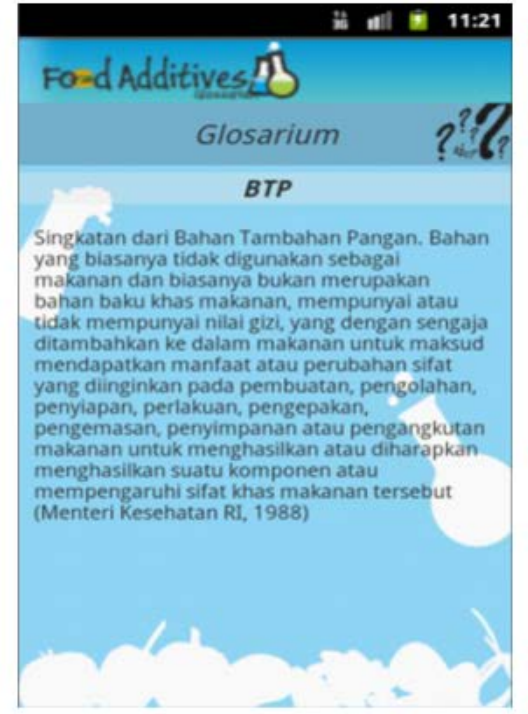

(c)

Figure 4. Profiles design

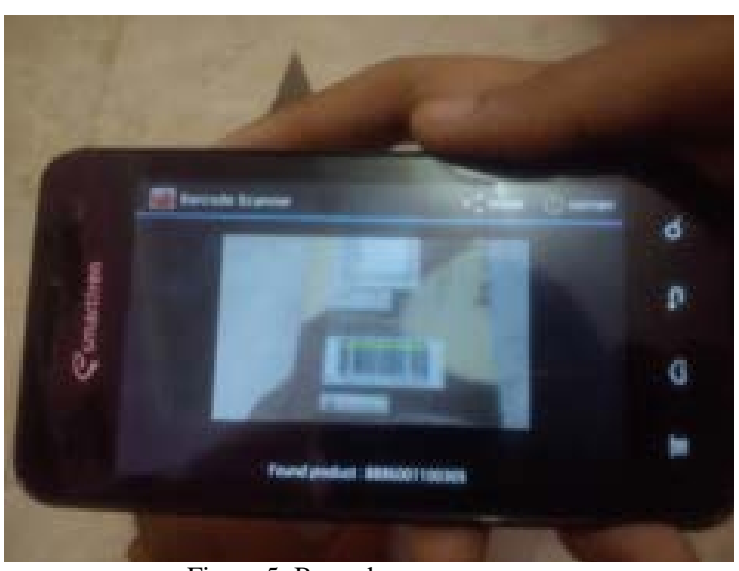

Figure 5. Barcode scanner usage

Mengecek versi database

(a)

\begin{tabular}{|l|}
\hline Data baru ditemukan \\
\hline Versi saat ini: 1.1 \\
Versi terbaru: 1.4 \\
Apakah anda ingin \\
memperbaharui data pada \\
aplikasi? \\
\multicolumn{1}{|c|}{ Tidak } \\
\hline
\end{tabular}

(b)

(c)

Figure 6. Update Process. 
TABLE 1.

List Of Products AND Its Food AdDitives Which Have BeEN Tested [1][7]

\begin{tabular}{|c|c|c|c|c|}
\hline \multirow{2}{*}{.No } & \multirow{2}{*}{ Product Name } & \multicolumn{3}{|c|}{ Food Additives } \\
\hline & & Name of food additives & Category & Halal Status \\
\hline & & Flavor & Suspect & Not known \\
\hline \multirow[t]{2}{*}{1} & Teh Pucuk Harum & & & \\
\hline & & Trikaliumphosphate & Safe & Halal \\
\hline \multirow[t]{3}{*}{2} & Tropicana Slim - classic 250g & Sorbitol & Unhealthy & Doubtful \\
\hline & & Flavor & Suspect & Not known \\
\hline & & Sukralosa & Unhealthy & Not known \\
\hline 3 & La Fonte - chicken sauce & Monosodium glutamate & Dangerous & Doubtful \\
\hline \multirow[t]{4}{*}{4} & Mie Sedap Goreng - 91g & Tartrazin & Unhealthy & Halal \\
\hline & & Monosodium glutamate & Dangerous & Doubtful \\
\hline & & Flavor & Suspect & Not known \\
\hline & & Sodium benzoate & Unhealthy & Halal \\
\hline \multirow[t]{9}{*}{5} & Mizone - lychee lemon & Asesulfam-K & Dangerous & Not known \\
\hline & & Sukralosa & Unhealthy & Not known \\
\hline & & Pektin & Safe & Halal \\
\hline & & Calcium lactate & Suspect & Doubtful \\
\hline & & Asam sitrat & Safe & Doubtful \\
\hline & & Flavor & Suspect & Not known \\
\hline & & Potassium sorbate & Dangerous & Halal \\
\hline & & Sodium benzoate & Unhealthy & Halal \\
\hline & & Magnesium sulfate & Unhealthy & Halal \\
\hline \multirow[t]{5}{*}{6} & Pocari Sweat & Potassium chloride & Unhelathy & Halal \\
\hline & & Calcium lactate & Suspect & Doubtful \\
\hline & & Magnesium carbonate & Suspect & Halal \\
\hline & & Ascorbic acid & Suspect & Conditional halal \\
\hline & & Flavor & Suspect & Not known \\
\hline \multirow[t]{5}{*}{7} & Oreo - double stuff & Tertiary butyl hydroquinone & Dangerous & Not known \\
\hline & & Sodium bicarbonate & Safe & Halal \\
\hline & & Ammonium bicarbonate & Suspect & Halal \\
\hline & & lecithin & Safe & Doubtful \\
\hline & & Flavor & Suspect & Not known \\
\hline
\end{tabular}


TABLE 1.

List Of Products AND ITs FoOd AdDITIVES Which HAVE BEEN TESTED (CONTINUED)

\begin{tabular}{|c|c|c|c|c|}
\hline \multirow{2}{*}{.No } & \multirow{2}{*}{ Product Name } & \multicolumn{3}{|c|}{ Food Additives } \\
\hline & & Name of food additives & Category & Halal Status \\
\hline 8 & Energen - vanilla 31g & calciumcarbonate & Safe & Conditional hala \\
\hline \multirow[t]{4}{*}{9} & Minute Maid - pulpy orange 350ml & Flavor & Suspect & Not known \\
\hline & & citric acid & Safe & Doubtful \\
\hline & & sodiumcitrate & Safe & Doubtful \\
\hline & & beta-carotene & Suspect & Conditional halal \\
\hline \multirow[t]{3}{*}{10} & Frestea Green - 250ml & Sodium bicarbonate & Safe & Halal \\
\hline & & sodium ascorbate & Safe & Halal \\
\hline & & Flavor & Suspect & Not known \\
\hline \multirow[t]{4}{*}{11} & Nutrisari - Jeruk manis & tricalciumphosphate & Unhealthy & Halal \\
\hline & & Flavor & Suspect & Not known \\
\hline & & tartrazine & Unhealthy & Halal \\
\hline & & Yellow FCF & Unhealthy & Halal \\
\hline \multirow[t]{5}{*}{12} & Sprite $-425 \mathrm{ml}$ & carbondioxide & Safe & Halal \\
\hline & & citric acid & Safe & Doubtful \\
\hline & & sodiumcitrate & Safe & Doubtful \\
\hline & & Sodium benzoate & Unhealthy & Halal \\
\hline & & Flavor & Suspect & Not known \\
\hline
\end{tabular}

